\author{
D.M. Frolov* \\ Geographical Faculty of Lomonosov Moscow State University, Moscow, Russia \\ *Corresponding author: denisfrolovm@mail.ru
}

\title{
Calculating scheme for ground freezing depth variations and its application in different landscapes
}

\begin{abstract}
Snow study is important because snow, after the ocean, is the second largest interface between the atmosphere and Earth's surface and it covers considerable part of the land during winter. Changes in snow cover extent and snowpack properties in recent decades in response to warming are ongoing and will likely continue in future. Ground thermal regime, despite the simplicity of measuring the ground temperature, remains an insufficiently studied field of landscapes. For determination of air-temperature influence, snow cover thickness, absolute values and the dynamics on the depth of ground freezing and thawing, a number of ground freezing models have been developed. In this work, the calculation is done with calculating scheme for ground freezing constructed on the basis of three-layer media heat conductivity problem (snow cover, frozen and thawed ground) with phase transition on the boundary of frozen and unfrozen ground. The heat balance equation includes phase transition energy, inflow of heat from unfrozen ground and outflow to frozen ground, snow cover and atmosphere. The heat flux is calculated on basis of Fourier law as a product of heat conductivity and temperature gradient. It is supposed that temperature changes linearly in each media. The calculations of ground freezing depth variations are done for plain and mountain regions. The ground freezing depth calculation results correspond to the observed values. Hence, the influence of the recent climate and weather contrasts and snow cover spatial and temporal variations on underlying ground freezing depth variations are investigated and reviled. This is vital, although climatic norms between 1961-1990 and 1991-2020 did not illustrate significant changes, but some strong weather variation extremes and contrasts (such as hotness in last 2020 year and weather anomalies of this 2020/2021 winter) are present in recent decades causing danger and risks for population and economics.
\end{abstract}

Keywords: calculation scheme, air temperature, snow cover, ground freezing, landscapes, mountain regions.

\section{Introduction}

As snow is one of the largest interfaces between the atmosphere and Earth's surface covering considerable part of the land during winter it is important to study snow. Changes in snow cover extent and snowpack properties in recent decades in response to warming are ongoing and will likely continue in future. Despite the simplicity of measuring the ground temperature, ground thermal regime remains today an insufficiently studied field of landscapes. This topic was essentially explored by A.V. Pavlov [1]. To determine the influence of air-temperature and snow cover thickness, absolute values and the dynamics on the ground freezing and thawing depth, a number of ground freezing models have been developed. For example, for his ground freezing depth estimation scheme, V.A. Kudriavtsev [2] characterized warming and cooling action of snow cover on the ground depending on snow accumulation regime, its duration and suggested equation for estimation of ground freezing depth including snow cover thickness, its thermal properties and amplitude of yearly air temperature oscillations. Applying this model, our calculation scheme for plain areas were done for observation site of Lomonosov Moscow State University for bare and covered with snow surface and for Moscow region. Verifying and proving the method consistency of the calculation, scheme was done according to the ground freezing depth and thermal regime observation data for plain regions where the data is available. For the rock ground freezing modeling, the model Alpine3D [3] consisting of the 3D atmospheric processes model coupled with the 1D energy balance model SNOWPACK was used. In this article, during the construction of debris flow and snow avalanche protecting installation in the mountain regions, the problem of fixation and stability of these constructions under the conditions of seasonally or permanently frozen ground arise. For this reason, the freezing depth of the soil is estimated based on the developed calculation scheme data on the thickness of the snow cover and air temperature for the Terskol weather station of the Elbrus region for winter periods 2015/16-2019/20. The calculating scheme for ground freezing is constructed on the basis of three-layer media heat conductivity problem (snow cover, frozen and thawed ground) with phase transition on the boundary of frozen and unfrozen ground. The heat balance equation includes phase transition energy, inflow of heat from unfrozen ground and outflow to frozen ground, snow cover and at- 
mosphere. The heat flux is calculated on basis of Fourier law as a product of heat conductivity and temperature gradient. It is supposed that temperature changes in each media linearly. The results of ground freezing depth calculations indicate that ground under snow cover stays frozen in the Elbrus region from December to April. At the same time, the ground under the snow-covered surface freezes according to calculations on average by 20 or more $\mathrm{cm}$. If the snow cover is partially or completely blown away, the ground may freeze to a depth of $1 \mathrm{~m}$ or even more and last for a longer period. Thus, the proposed method allows to evaluate soil freezing as a factor of soil stability for the protection of constructions.

\section{Experimental}

In this paper, we calculate freezing depth based on data on air temperature and snow cover thickness applying the proposed calculation scheme for weather station of Lomonosov Moscow State University and Moscow region weather stations (for number of winter seasons for verifying and proving the consistency), and for Terskol meteorological station (for the snow-covered soil surface of the winter seasons 2015/162019/20). The calculation scheme was based on the problem of thermal conductivity of a three-layer medium (snow, frozen and thawed soil) with a phase transition at the boundary of frozen and thawed soil. The heat balance equation included the energy of the phase transition, the inflow of heat from the thawed ground and the outflow to the frozen ground and, in the presence of snow cover, through it to the atmosphere. The heat flux was calculated considering Fourier law, as the product of the thermal conductivity and the temperature gradient. It was assumed that the temperature in each medium varies linearly (for example, $[4,5]$ ). For snow cover and frozen ground, the formula of thermal conductivity of a two-layer medium was used.

The calculation of ground freezing based on data on air temperature and snow cover thickness and thermal conductivity during the winter period made it possible to estimate the intensity of the freezing front movement during this period. The dependence of the speed of the freezing front movement was found according to the calculated scheme. The scheme took into account the freezing of the ground from below on the frozen ground mass in winter based on data on the daily air temperature (the thickness and thermal conductivity of the snow cover).

The heat balance equation was written as

$$
F_{1}=c L V+F_{2}
$$

or as:

$$
d h_{f g} / d t=V=\left(F_{1}-F_{2}\right) / c L,
$$

where $F_{1}$ - heat outflow through the frozen ground (and snow cover) from the freezing front $\left(\mathrm{W} / \mathrm{m}^{2}\right)$ to the atmosphere; $c L V=c L d h_{f g} / d \tau$ - consumption heat at the phase transition; $c$ - moisture content of the soil $\left(1-4 \mathrm{~kg} / \mathrm{cm}^{*} \mathrm{~m}^{2}\right)$, (last value corresponds to the complete filling of pores with water from a lightweight clay with a density of $2000 \mathrm{~kg} / \mathrm{m}^{3}$ and a porosity 0,617 [1]); $L$ - energy of the phase transition $(335 \mathrm{~kJ} / \mathrm{kg})$; $V=d h_{f g} / d t$ - the speed of the freezing front $(\mathrm{cm} / \mathrm{s}) ; F_{2}$ - heat exchange in the cooling melt the ground before the freezing front $\left(\mathrm{W} / \mathrm{m}^{2}\right)$.

The heat flux was expressed according to the Fourier law: $F=-\lambda \operatorname{grad} T$. The heat flow through the frozen ground from the freezing front to the atmosphere in the case of snow cover was expressed in terms of thermal conductivity and heat flow of a combination of two media (snow cover and frozen ground):

$$
F_{1}=-\lambda \frac{\Delta T}{\Delta x}=-\frac{\Delta T}{\frac{\Delta x_{s}}{\lambda_{s}}+\frac{\Delta x_{f g}}{\lambda_{f g}}}=\frac{-T_{a i r}}{\frac{h_{s}}{\lambda_{s}}+\frac{h_{f g}}{\lambda_{f g}}},
$$

here $T_{\text {air }}$ is the air temperature, $h_{\mathrm{s}}$ and $h_{\mathrm{fg}}$ are the snow thickness and freezing depth, and $\lambda_{\mathrm{s}}$ and $\lambda_{f g}$ are the thermal conductivity of snow and frozen ground.

It was assumed that at a depth of $10 \mathrm{~m}$ in the ground, there is a point of zero annual temperature fluctuations $T_{0}$ with an average annual value of about $7^{\circ} \mathrm{C}$. Therefore

$$
F_{2}=-\lambda_{\text {thg }} \frac{\Delta T}{\Delta x}=\lambda_{\text {thg }} \frac{T_{0}}{10-h_{\text {thg }}},
$$

here $\lambda_{\text {th }}$ is the thermal conductivity of thawed soil. Calculations were performed in one-day increments. At first, it was considered that the thickness of the frozen ground $h_{\mathrm{fg}}$ was $0.5 \mathrm{~cm}$. The freezing rate $V$ and the value of the frozen ground thickness $h_{\mathrm{fg}}$ was calculated for the next day (time step). According to [6], the average thermal conductivity of thawed and frozen clay soil could be taken as 1.4 and $1.8 \mathrm{~W} / \mathrm{m}^{\circ} \mathrm{C}$. The average thermal conductivity of snow $\lambda_{c}$ was calculated relatively to the density according to the formula of A.V. Pavlov [1] and was taken equal to $0.18 \mathrm{~W} / \mathrm{m}^{\circ} \mathrm{C}$. 


\section{Results and Discussion}

In this paper, a difference scheme was constructed for the derived first-order time differential equation for changing the depth of soil freezing by approximating this differential equation by the explicit Euler method: $h_{\mathrm{fg}}\left(t_{\mathrm{n}+1}\right)=h_{\mathrm{fg}}\left(t_{\mathrm{n}}\right)+\Delta T V\left(t_{\mathrm{n}}\right)$. According to the obtained difference scheme, each winter season of recent decade calculations of ground freezing depth variations were performed of plain observation site of Lomonosov Moscow State University for verification and mountain of Terskol meteorological station. An example of the calculation results of mountain of Terskol meteorological station for the winter season 2016/17 is shown on the Figure 1.

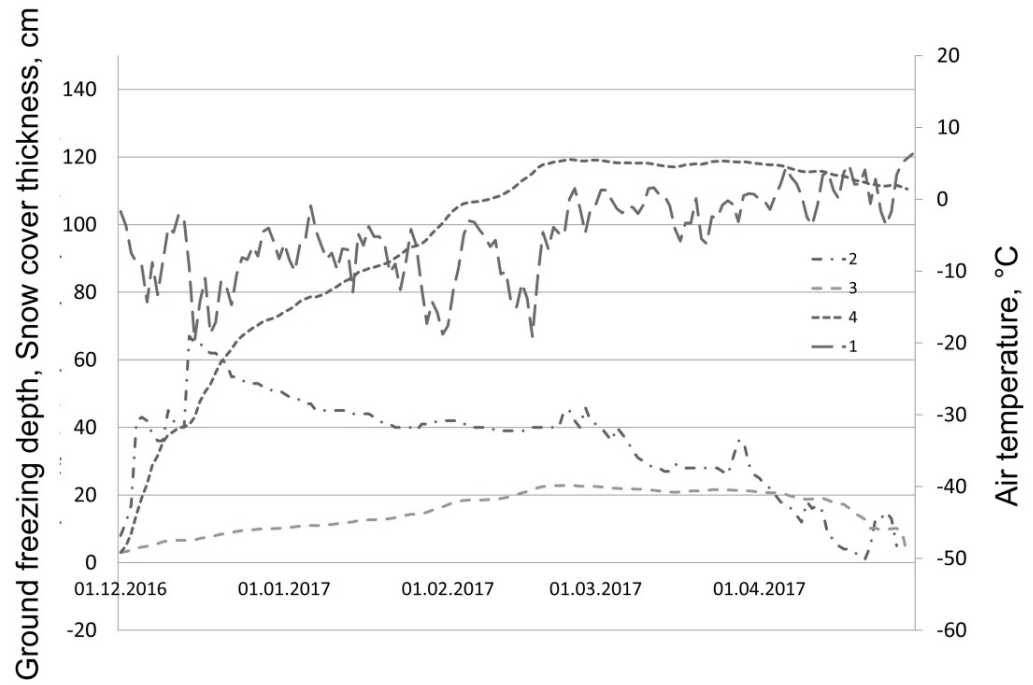

1 - air temperature; 2 - thickness of snow cover; 3 - estimated depth of freezing of the ground under the snow cover; 4 - estimated depth of freezing of exposed ground

Figure 1. Changes in air temperature and freezing depth based on calculations for snow-covered and exposed ground surfaces of a weather station Terskol for winter period 2016/17

The example of results of calculations of ground freezing depth for plain under bare and covered with snow site surface of the meteorological observatory of Lomonosov Moscow State University for the winter period 2017/18 and their comparison with the observed data are displayed in the Figure 2.

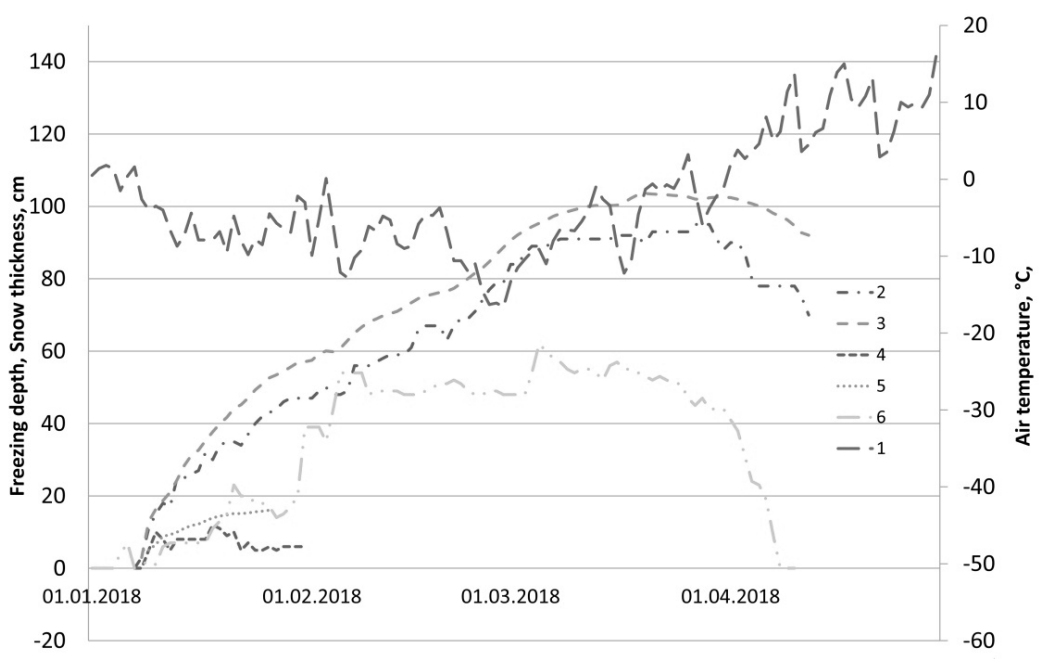

The results of calculations for ground freezing depth for the bare (3) and covered with snow site surface (5) and their comparison with the observed data ( 2 and 4 correspondingly). Air temperature $(1)$ and snow cover thickness $(6)$

Figure 2. Variations of air temperature and ground freezing depth according to the data of calculations and observation under bare and covered with snow site surface of the meteorological observatory of Lomonosov Moscow State University for the winter period 2017/18 
The results of calculations of maximal ground freezing depth for the bare site surface of the meteorological observatory of Lomonosov Moscow State University for the winter periods of 2011/12-2017/18 and their comparison with the observed data are demonstrated in Table 1 indicating general consistency of the calculating method.

Ta b l e 1

Comparison of calculated and observed maximal ground freezing depth under bare and covered with snow site surface of the meteorological observatory of Lomonosov Moscow State University for the winter periods of 2011/12-2017/18

\begin{tabular}{|c|c|c|c|c|}
\hline \multirow[t]{2}{*}{ Winter period } & \multicolumn{2}{|c|}{$\begin{array}{l}\text { Maximal ground freezing depth under bare site } \\
\text { surface, } \mathrm{cm}\end{array}$} & \multicolumn{2}{|c|}{$\begin{array}{l}\text { Maximal ground freezing depth for the covered } \\
\text { with snow site surface, } \mathrm{cm}\end{array}$} \\
\hline & observed & calculated & observed & calculated \\
\hline $2011 / 12$ & 120 & 110 & 18 & 10 \\
\hline $2012 / 13$ & 118 & 120 & 8 & 12 \\
\hline $2013 / 14$ & 100 & 87 & 18 & 4 \\
\hline $2014 / 15$ & 95 & 85 & 30 & 7 \\
\hline $2015 / 16$ & 78 & 88 & 25 & 30 \\
\hline $2016 / 17$ & 100 & 100 & 3 & 7 \\
\hline $2017 / 18$ & 95 & 105 & 14 & 18 \\
\hline Max diff. & \multicolumn{2}{|c|}{13} & \multicolumn{2}{|c|}{23} \\
\hline Min diff. & \multicolumn{2}{|c|}{-10} & \multicolumn{2}{|c|}{-5} \\
\hline Aver. diff. & \multicolumn{2}{|c|}{1,6} & \multicolumn{2}{|c|}{4} \\
\hline
\end{tabular}

From the Table 1 one can see that averaged difference of calculated and observed maximal ground freezing depth under bare site surface of the meteorological observatory of Lomonosov Moscow State University for the winter periods of 2011/12-2017/18 is $1.6 \mathrm{~cm}$ and under the covered with snow site surface it is $4 \mathrm{~cm}$. The main advantage of the calculating scheme is that it reproduces the dynamic of the ground freezing process well. So, the calculation method is physically well-justified. The solution method thoroughly describes the process of changing the freezing depth during the winter season. It is important for the successful operation of the method to set the initial data as accurately as possible.

The proven consistency of the method allows to predict that the results of calculating the maximum ground freezing depth for Terskol weather station are valid. These results are demonstrated in Table 2.

T a b l e 2

Variations in the maximum ground freezing depth, average snow cover thickness for February and the sum of negative monthly temperatures for Terskol weather station for winter periods 2015/16-2019/20

\begin{tabular}{|c|c|c|c|c|}
\hline $\begin{array}{c}\text { Winter } \\
\text { period }\end{array}$ & $\begin{array}{c}\text { Sum of negative } \\
\text { monthly } \\
\text { temperature, }{ }^{\circ} \mathrm{C}\end{array}$ & $\begin{array}{c}\text { Averaged February snow } \\
\text { cover thickness, cm }\end{array}$ & $\begin{array}{c}\text { Max. freezing depth } \\
\text { of snow-covered ground, cm }\end{array}$ & $\begin{array}{c}\text { Max. freezing depth of } \\
\text { exposed ground, cm }\end{array}$ \\
\hline $2015 / 16$ & $-18,7$ & 60 & 21 & 97 \\
\hline $2016 / 17$ & $-27,7$ & 40 & 23 & 83 \\
\hline $2017 / 18$ & $-14,2$ & 70 & 8 & 96 \\
\hline $2018 / 19$ & $-19,4$ & 60 & 20 & \\
\hline $2019 / 20$ & & & 20 & \\
\hline
\end{tabular}

\section{Conclusions}

As indicated in Table 2 the thickness of the accumulated snow cover on the mountain Terskol weather station can reach half a meter or more. At the same time, the ground under the snow-covered surface freezes according to calculations by an average of 20 centimeters or more. In the case of partial or complete blowing off of the snow cover, freezing of the ground can occur to a depth of 1 meter or more and last for a longer period. Thus, the proposed method for calculating the dynamics of the ground freezing depth on basis of data on air temperature and snow cover thickness allows to assess the variation of ground freezing depth in different landscapes. It is also necessary to mention that for the mountain Terskol weather station, we do not have values of ground freezing depth for verification, but only air temperature and snow cover thickness. Howev- 
er, we rely on the proven general consistency of the calculating scheme for the plain territory where the verification data of ground freezing depth is available.

\title{
Acknowledgments
}

The work was performed in the frame of state topic "Danger and risk of natural processes and phenomena" (121051300175-4).

\section{References}

1 Павлов А.В. Теплофизика ландшафтов / А.В. Павлов. — Новосибирск: Наука, 1979. — 284 с.

2 Кудрявцев В.А. Температура верхних горизонтов вечномерзлой толщи в пределах СССР / В.А. Кудрявцев. - М.: Изд-во АН СССР, 1954. - 183 с.

3 Haberkorn A. Distributed snow and rock temperature modeling in steep rock walls using Alpine3D / A. Haberkorn, N. Wever, M. Hoelzle, M. Phillips, R. Kenner, M. Bavay, M. Lehning // The Cryosphere. - 2016. - Vol. 11, Issue 1. - P. 585-607. https://doi.org/10.5194/tc-2016-73

4 Фролов Д.М. Расчёт глубины промерзания грунта под оголённой и покрытой снегом поверхностью на метеостанции МГУ за зимние периоды 2011/12-2017/18 / Д.М. Фролов // Динамика окружающей среды и глобальные изменения климата. - 2019. - T. 10, № 2. - C. 86-90.

5 DeGaetano A.T. Physical simulation of maximum seasonal soil freezing depth in the united states using routine weather observations / A.T. DeGaetano, M.D. Cameron, D.S. Wilks // Journal of Applied Meteorology. — 2001. — Vol. 40, № 3. — P. $546-555$.

6 Трофимов В.Т. Грунтоведение / В.Т. Трофимов. - М.: Изд-во МГУ; Наука, 2005. — 1024 с.

7 Golubev V.N. Winter regime of temperature and precipitation as a factor of snow-cover distribution and its stratigraphy / V.N. Golubev, M.N. Petrushina, D.M. Frolov // Annals of Glaciology. — 2008. — Vol. 49. — P. 179-186.

\section{Д.М. Фролов}

\section{Топырақтың қату тереңдігінің өзгеруінің есептік сызбасы және оны әртүрлі ландшафттарда қолдану}

\begin{abstract}
Қарды зерттеу өте маңызды, өйткені мұхиттан басқа, қар атмосфера мен жер беті арасындағы екінші үлкен байланыс болып табылады, ал қыста қар жердің едәуір бөлігін қамтиды. Соңғы онжылдықтарда жылынуға жауап ретінде қар жамылғысының ауданы мен қасиеттерінің өзгеруі жалғасуда және болашақта да жалғасуы мүмкін. Топырақтың жылу режимі, топырақ температурасын өлшеу қарапайымдылығына қарамастан, бүгінде ландшафттардың аз зерттелген аймағы болып қала береді. Абсолютті мәндер мен ауа температурасының динамикасы мен қар жамылғысының қалыңдығы топырақтың қату және еріту тереңдігіне әсерін анықтау үшін топырақты қатырудың бірқатар модельдері жасалды. Мақалада есептеу мұздатылған және мұздатылмаған Gru шекарасында фазалық ауысумен үш қабатты ортаның (қар жамылғысы, мұздатылған және еріген топырақ) жылу өткізгіштік міндеті негізінде салынған топырақты мұздатудың есептік схемасы бойынша жүзеге асырылған. Жылу балансының теңдеуі фазалық ауысу энергиясын, мұздатылмаған топырақтан жылу ағынын және мұздатылған жерге жылу ағынын, қар жамылғысы мен атмосфераны қамтиды. Жылу ағыны Фурье заңына сәйкес жылу өткізгіштік пен температура градиентінің көбейтіндісі ретінде есептелді. Әр ортадағы температура сызықтық өзгереді деп болжанған. Топырақтың қату тереңдігінің өзгеру есептері жазық және таулы аудандар үшін есептелді. Топырақтың қату тереңдігін есептеу нәтижелері байқалған мәндерге сәйкес келеді. Осылайша, соңғы климаттық және ауа-райының қарамақайшылықтарының әсері, сондай-ақ қар жамылғысының кеңістіктік және уақытша өзгерістері, топырақтың қату тереңдігінің өзгеруі зерттелген және талқыланған. Бұл өте маңызды, өйткені климаттық нормалар 1961 жылдан 1990 жылға дейін және 1991 жылдан 2020 жылға дейін айтарлықтай өзгерген жоқ, бірақ ауа-райының ауытқуы мен қарама-қайшылықтары өте қатты болды (мысалы, өткен 2020 жылы өте ыстық ауа-райы және 2020/2021 ж. қыстағы ауа-райының ауытқуы). Бұл халық пен экономика үшін қауіп пен қатер тудырады.
\end{abstract}

Кілт сөздер: есептік схема, ауа температурасы, қар жамылғысы, топырақтың қатуы, ландшафттар, таулы аудандар. 


\title{
Д.М. Фролов \\ Расчётная схема изменения глубины промерзания грунта и ее применение в различных ландшафтах
}

\begin{abstract}
Изучение снега важно, потому что, за исключением океана, снег является вторым по величине связующим звеном между атмосферой и поверхностью Земли, а зимой снег покрывает значительную часть суши. Изменения площади и свойств снежного покрова в последние десятилетия в ответ на потепление продолжаются и, вероятно, найдут продолжение в будущем. Термический режим грунта, несмотря на простоту измерения его температуры, на сегодняшний день остается мало изученной областью ландшафтов. Для определения влияния абсолютных значений, динамики температуры воздуха и толщины снежного покрова на глубину промерзания и оттаивания грунта разработан ряд моделей промерзания грунта. В статье расчет проводился по расчетной схеме промерзания грунта, построенной на основе задачи теплопроводности трехслойных сред (снежный покров, мерзлый и талый грунт), с фазовым переходом на границе мерзлого и незамерзшего грунта. Уравнение теплового баланса включает энергию фазового перехода, приток тепла из незамерзшей почвы и отток тепла в мерзлую землю, снежный покров и атмосферу. Тепловой поток рассчитывается по закону Фурье как произведение теплопроводности и градиента температуры. Предполагается, что температура в каждой среде изменяется линейно. Расчеты изменения глубины промерзания грунта выполнены для равнинных и горных районов. Результаты расчета глубины промерзания грунта соответствуют наблюдаемым значениям. Таким образом, исследуется и осуждается влияние недавних климатических и погодных контрастов, а также пространственных и временных вариаций снежного покрова на вариации глубины промерзания подстилающей почвы. Это действительно важно, потому что, хотя климатические нормы в период с 1961 по 1990 г. и с 1991 по 2020 гг. изменились не очень существенно, однако проявились экстремальные погодные колебания и контрасты (например, очень жаркая погода в прошлом 2020 г. и погодные аномалии этой зимы 2020/2021 г.) в последние десятилетия. Это создаёт опасность и риски для населения и экономики.
\end{abstract}

Ключевые слова: расчетная схема, температура воздуха, снежный покров, промерзание грунта, ландшафты, горные районы.

\section{References}

1 Pavlov, A.V. (1979). Teplofisika landshaftov [Thermal physics of landscapes]. Novosibirsk: Nauka [in Russian].

2 Kudryavtsev, V.A. (1954). Temperatura verkhnikh gorizontov vechnomerzloi tolshchi v predelakh SSSR [Temperature of the upper horizons of the permafrost layer within the USSR]. Moscow: Publishing House of the USSR Academy of Sciences [in Russian].

3 Haberkorn, A., Wever, N., Hoelzle, M., Phillips, M., Kenner, R., Bavay, M., \& Lehning, M. (2017). Distributed snow and rock temperature modeling in steep rock walls using Alpine3D. The Cryosphere, 11 (1), 585-607. https://doi.org/10.5194/tc-2016-73

4 Frolov, D.M. (2019). Calculations of ground freezing depth under bare and covered with the snow cover ground surface for the site of the meteorological observatory of Lomonosov Moscow State University for winter periods of 2011/12-2017/18. Environmental Dynamics and Global Climate Change, 10 (2), 86-90. https://doi.org/10.17816/edgcc21203

5 DeGaetano, A.T., Cameron, M.D., \& Wilks, D.S. (2001). Physical simulation of maximum seasonal soil freezing depth in the United States using routine weather observation. Journal of Applied Meteorology, 40 (3), 546-555.

6 Trofimov, V.T. (2005). Gruntovedenie [Soil science]. Moscow: MSU Publ. House; Nauka [in Russian].

7 Golubev, V.N., Petrushina, M.N., \& Frolov, D.M. (2008). Winter regime of temperature and precipitation as a factor of snow-cover distribution and its stratigraphy. Annals of Glaciology, 49, 179-186. 